\title{
Lingual thyroid presenting as menorrhagia
}

\author{
*J Hettiarachchi ${ }^{1}$, M H M Nazmy ${ }^{1}$, H D K S K Thilakarathna ${ }^{1}$, T M R Perera ${ }^{2}$, V P Sinhabahu ${ }^{3}$
}

Sri Lanka Journal of Child Health, 2019; 48(2): 179-180

DOI: http://dx.doi.org/10.4038/sljch.v48i2.8719

(Key words: Lingual thyroid, menorrhagia)

\section{Case report}

A previously healthy, 12 year old girl presented with abdominal pain, exertional dyspnoea and heavy menstrual bleeding with clots for fifteen days. There were no other bleeding manifestations. She was the third child of healthy nonconsanguineous parents with two healthy siblings. Since she attained menarche two months prior to admission, she had monthly periods which lasted two weeks. Her development was age appropriate with average school performance. Her height was $134 \mathrm{~cm}\left(0.4^{\text {th }}-2^{\text {nd }}\right.$ centile $)$, weight $38 \mathrm{~kg}$ and body mass index (BMI) $21.2 \mathrm{~kg} / \mathrm{m}^{2}\left(85^{\text {th }}-95^{\text {th }}\right.$ centile). Her height was within mid-parental height range. She had a nonverbal IQ of 121 . She was pale without any features of heart failure.

Examination showed a distended abdomen with firm, non tender, hepatomegaly $(4 \mathrm{~cm}$ below the costal margin) without other organomegaly or free fluid. Respiratory and central nervous system examinations were normal. Her full blood count showed macrocytic anaemia with haemoglobin $7.1 \mathrm{~g} / \mathrm{dl}$, mean corpuscular volume (MCV) 101.2fl, mean corpuscular haemoglobin (MCH) 30.1pg, mean corpuscular haemoglobin concentration (MCHC) $29.7 \mathrm{~g} / \mathrm{dl}$ and red cell distribution width (RDW) $17.6 \%$. The clotting profile was normal. Thyroid stimulating hormone (TSH) level was above 100 milli international units per litre with the free thyroxine level $0.18 \mathrm{ng} / \mathrm{dl}$. Ultrasound scan of the neck did not show thyroid tissue at the thyroid bed or in ectopic locations. Technetium-99m (99m Tc) thyroid scan revealed isotope uptake only at the

${ }^{1}$ Registrar in Paediatrics, ${ }^{2}$ Senior Lecturer and Consultant Paediatrician, ${ }^{3}$ Senior Registrar in Paediatrics, Professorial Paediatric Unit, Colombo South Teaching Hospital, Kalubowila, Sri Lanka *Correspondence: jeevanee@ymail.com

https://orcid.org/0000-0002-2601-9709

(Received on 26 June 2017: Accepted after revision on 18 August 2017)

The authors declare that there are no conflicts of interest Personal funding was used for the project.

base of the tongue confirming a lingual thyroid without thyroid tissue in the normal location (Figure 1).

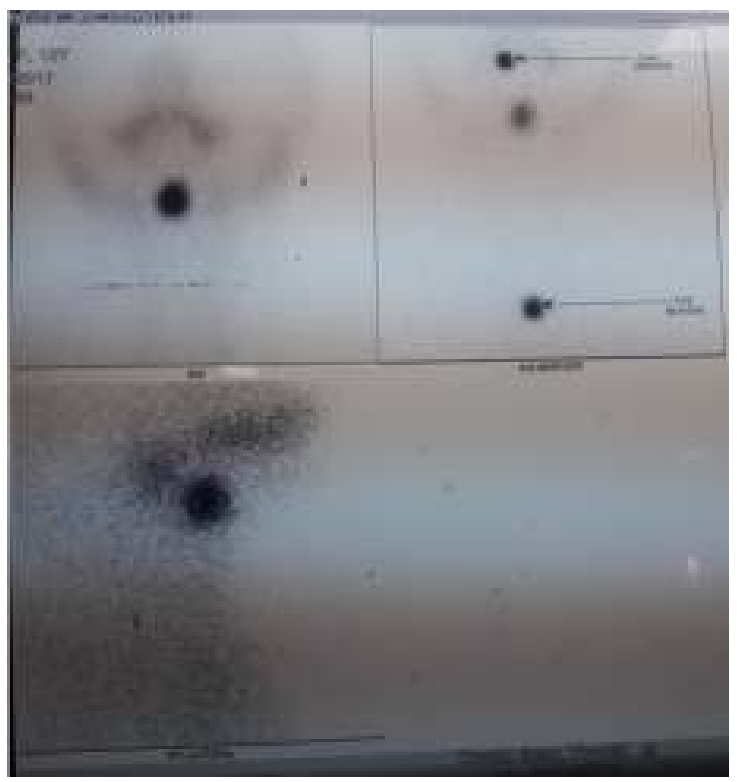

Figure 1: Tc 99 thyroid scan

Antithyroid antibody screen showed that the antithyroglobulin antibody level was $10.51 \mathrm{IU} / \mathrm{ml}$ (normal $<4.1 \mathrm{IU} / \mathrm{ml}$ ) and thyroid peroxidase antibody level was $21.3 \mathrm{IU} / \mathrm{ml}$ (normal $<35 \mathrm{IU} / \mathrm{ml}$ ). Liver function tests showed the alanine transaminase (ALT) level was $153.9 \mathrm{U} / \mathrm{l}$, the aspartate transaminase (AST) was $144.1 \mathrm{U} / 1$ and the alkaline phosphatase (ALP) level was 192.9 U/1. Lipid profile showed a high total cholesterol level of $440.4 \mathrm{mg} / \mathrm{dl}$, a triglyceride level of 207.3 $\mathrm{mg} / \mathrm{dl}$, a high density lipoprotein (HDL) level of $54.5 \mathrm{mg} / \mathrm{dl}$, a low density lipoprotein (LDL) level of $344.9 \mathrm{mg} / \mathrm{dl}$ and a very low density lipoprotein (VLDL) level of $41 \mathrm{mg} / \mathrm{dl}$. Chest $\mathrm{x}$ ray showed cardiomegaly (Figure 2).

The electrocardiogram (ECG) was normal. Two dimensional echocardiogram (2D ECHO) showed a mild pericardial effusion with normal ejection fraction. Ultrasound scan of the abdomen showed hepatomegaly with a liver span of $17 \mathrm{~cm}$ and grade 2 fatty liver. Radiograph of the left hand showed delayed bone age where the chronological age was 144 months and the bone age was $120 \pm 21.6$ months. Serum corrected calcium level was $2.28 \mathrm{mmol} / 1(2.2-2.7 \mathrm{mmol} / \mathrm{l})$. She was started on 
thyroxine 100 micrograms daily and haematinics. She is being followed up in the clinic for hypothyroidism and anaemia.

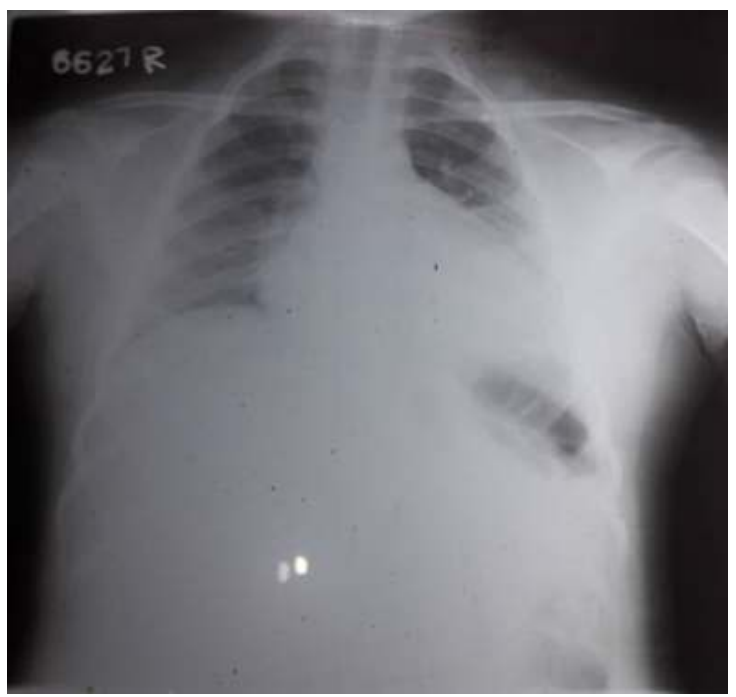

Figure 2: Chest $x$-ray

\section{Discussion}

Hypothyroidism can be either congenital or acquired. Thyroid dysgenesis, including thyroid agenesis, hypoplasia and ectopy is the cause of $85 \%$ of congenital hypothyroidism ${ }^{1,2}$. The incidence of lingual thyroid is reported as $1: 100,000$ with a 1:7 female predominance ${ }^{3}$. Lingual thyroid can present as failure to thrive and mental retardation in infants and young children or can be detected via routine screening ${ }^{3}$. Other cases may present with slowly progressing dysphagia and oropharyngeal obstruction ${ }^{4}$. Puberty and pregnancy can lead to an increase in gland size due to increase need for thyroxine which precipitates symptoms.

Hypothyroidism can present as sexual pseudoprecocity. The exact mechanism of sexual pseudoprecocity is not clear. The ectopic thyroid tissue can be the only functional thyroid tissue. This must be kept in mind when determining the therapeutic approach. Asymptomatic cases can be monitored with suppressive hormonal therapy aiming at reduction of ectopic tissue volume as in lingual thyroid $^{3}$. Definitive treatment for lingual thyroid is surgical excision provided that adequate thyroid tissue is found in the neck ${ }^{5}$. Indications for surgical intervention are dyspnoea or dysphagia, suspicion of malignancy, uncontrolled hyperthyroidism and repetitive or severe bleeding.

Our patient has dyslipidaemia, steatohepatitis and marginally delayed bone age as complications of hypothyroidism. As her height is within the mid parental height and she has normal intelligence quotient (IQ) with raised antithyroglobulin antibodies, she probably had acquired hypothyroidism due to lingual thyroid which failed due to the increased metabolic demand in puberty or due to autoimmune destruction. Extensive literature survey did not show a similar patient. Menorrhagia with significant anaemia may be the only presentation in hypothyroidism. Search for thyroid tissue in ectopic locations is important to avoid complications.

\section{References}

1. Rastogi MV, LaFranchi SH. Congenital hypothyroidism. Orphanet Journal of Rare Diseases 2010; 5: 17.

https://doi.org/10.1186/1750-1172-5-17

PMid: 20537182 PMCid: PMC2903524

2. Castanet M, Polak M, Bonaïti-Pellié C, Lyonnet $\mathrm{S}$, Czernichow $\mathrm{P}$, Léger $\mathrm{J}$. Nineteen years of national screening for congenital hypothyroidism: Familial cases with thyroid dysgenesis suggest the involvement of genetic factors. Journal of Clinical Endocrinology and Metabolism 2001; 86(5): 2009-14.

https://doi.org/10.1210/jcem.86.5.7501

PMid: 11344199

3. Babademez M A, Günbey E, Acar B, Günbey H P. A rare cause of obstructive sleep apnoea syndrome: lingual thyroid. Sleep and Breathing 2012; 16(2): 305-8.

https://doi.org/10.1007/s11325-011-05060

PMid: 21494851

4. Toso A, Colombani F, Averono G, Aluffi $P$, Pia F. Lingual thyroid causing dysphagia and dyspnoea. Case reports and review of the literature. Acta Otorhinolaryngologica Italica 2009; 29(4):213-7.

PMid: 20161880 PMCid: PMC2816370

5. Kumar SS, Kumar DMS, Thirunavukuarasu R. Lingual ThyroidConservative management or surgery? A case report. The Indian Journal of Surgery. 2013; 75(Suppl 1):118-9. https://doi.org/10.1007/s12262-012-05184

PMid: 24426535 PMCid: PMC3693310 